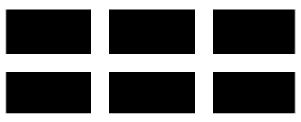

ThE William DAVIDSON INSTITUTE AT THE UNIVERSITY OF MICHIGAN BUSINESS SCHOOL

\title{
Resolution, Recovery and Survival: The Evolution of Payment Disputes in Post-Socialist Europe
}

\author{
By: William Pyle
}

William Davidson Institute Working Paper Number 761

March 2005 
Resolution, Recovery and Survival:

The Evolution of Payment Disputes in Post-Socialist Europe

William Pyle

Middlebury College

Middlebury, VT 05753

(802) 443-3240

wpyle@middlebury.edu 


\title{
Resolution, Recovery and Survival:
}

\section{The Evolution of Payment Disputes in Post-Socialist Europe}

\begin{abstract}
What determines the mechanism chosen to resolve a commercial dispute? To what degree does the aggrieved recover damages? And does the relationship survive in the aftermath? The answers to these questions affect expectations as to the costs of transacting and, thereby, the development of markets. But they have received almost no attention in the economic literature on the post-socialist transition. This article exploits a rich survey of small and medium-sized manufacturing enterprises in three post-socialist countries to explain behavioral responses to an inter-firm payment dispute. Particular attention is given to how the evolution of disputes is sensitive to both the geographic distance between trade partners and membership in a business association.
\end{abstract}

Keywords: $\quad$ commercial dispute, business association, transition

JEL classification: D23, D74, K40, K41, P37 


\section{Resolution, Recovery and Survival: The Evolution of Payment Disputes in Post-Socialist Europe ${ }^{1}$}

\section{Introduction}

Throughout history, the expansion of markets has depended upon the development of mechanisms to uphold agreements and resolve disputes. By raising the costs of non-compliance, effective enforcement institutions reduce the incidence of contractual violations, thus emboldening otherwise reluctant firms to widen their circle of trade partners. The post-socialist experience has re-focused attention on this fundamental lesson of "market building." From mafia organizations (Frye and Zhuravskaya, 2000; Leitzel et al., 1995; Varese, 2001), to bi- and multilateral reputation mechanisms (Hendley and Murrell, 2003; Johnson et al., 2002; Pyle, 2005), to the nascent court system (Hendley, 2001), transition countries developed, in relatively short order, a diverse array of institutions for imposing costs on parties that renege on commercial agreements.

Although a fair number of studies describe these institutions and illustrate how they contribute to the expansion of markets, few have actually made what they are designed to prevent - commercial disputes - the unit of analysis. In spite of the evolution of institutions to prevent them, commercial disputes still occur - and possibly with greater frequency. ${ }^{2}$ When they do, we are not well informed as to what happens next: What determines the mechanism chosen to resolve the dispute? To what degree does the aggrieved party recover damages? And does the commercial relationship survive in the dispute's aftermath? It is not unreasonable to believe that the answers to these questions affect general expectations as to the costs of transacting and, thereby, the development of markets. Nevertheless, these questions have received almost no attention in the economic literature on the post-socialist transition. The one noteworthy study that considers the evolution of business disputes is based on a limited selection of case studies (Hendley, 2004). None, to our knowledge, use the power of large micro-datasets to address these matters.

This article addresses this gap in the literature by shedding light on dispute resolution within a specific transitional context. Using a rich survey of small and medium-sized 
manufacturing enterprises in three post-socialist countries (Johnson, McMillan and Woodruff, 2000), we examine responses relating to a firm's most recent payment dispute with a customer to explore why some disputes end up in the courts while others do not, why some claimants eventually receive a greater percentage of the amount in question, and why some relationships survive in the aftermath. ${ }^{3}$ An expected cost-benefit calculus is presumed to guide behavior at each of these several stages in the wake of an inter-firm dispute. The resolution method selected, for example, should depend upon the opportunity cost of going to court. And the mutual desire to continue transacting after a dispute has ended should be determined by firms' ex post evaluation of the relationship's value. This general approach leads to the identification of behavioral correlates at both the firm and relationship levels.

Inspired by the economics research chronicling the development of enforcement mechanisms through history, particular attention is given to the roles played by both geography and institutions for inter-firm information exchange (North, 1990). An important theme from this literature is that the enforcement mechanisms that evolve to support arms-length transacting are sensitive to the geographic expanse of the market. Greater distances between parties give rise to greater transaction costs, which can be attenuated by non-public institutions that operate on the basis of reputational sanctions. Greif (1993), for instance, demonstrates how the rich flow of information among dispersed Maghribi traders reduced the risk associated with trade between Mediterranean Sea ports in the eleventh century. And Milgrom et al. (1990) show how the Champagne Fairs of medieval times developed mechanisms to centralize records of traders' transactional histories, thereby discouraging breach of contract and allowing for identification of reliable partners from distant locales. One contemporary analog to these historical institutions is a business association, a non-commercial organization designed to promote the general interests of members. Such associations may support the expansion of markets by improving relational contracting, which can be particularly valuable in environments with under-developed public institutions for contract enforcement (Doner and Schneider, 2000; Woodruff, 1998).

The evidence presented in this article confirms that geographic distance raises costs associated with experiencing a payment dispute. The likelihood of recovering a debt is shown to drop in the distance between trade partners, particularly if an international border intervenes. Moreover, the probability of a relationship surviving a dispute, thus diminishing the need to search for and screen new partners, declines with distance. These costs appear, however, to be 
mitigated by business associations, which, our evidence suggests, play a role that complements the formal legal system. Business association members are shown to recover a higher percentage of a disputed payment and are more likely to maintain a relationship in the aftermath of a disagreement. Though the mechanism through which associations reduce their members' dispute-related costs cannot be precisely identified, the evidence presented here is consistent with the proposition that associations play an important role promoting inter-firm flows of information and, thereby, assisting the development of markets.

The article is structured as follows. Section 2 reviews the relevant literature on inter-firm payment disputes, business associations and the post-socialist transition. In the third section, the data for analyzing the evolution of payment disputes are presented. Sections 4 and 5 investigate the factors that affect, respectively, courts' involvement and the dispute's costs - in terms of unrecovered payments and severed relationships - to the creditor. The final section presents conclusions and implications.

\section{Payment Disputes and their Resolution in Comparative Perspective}

It is common practice for suppliers not to require customers to pay in full either in advance or at the time of delivery. Instead, they offer trade credit in return for a promise to be compensated at a later date. In aggregate terms, these credits can add up to an impressive amount of commercial lending. Indeed, in a number of industrialized countries, the stock of trade credit (or accounts receivable) amounts to as much as $25 \%$ of firms' assets and $40 \%$ of GDP. As with loans of any type, suppliers offering trade credit assume a risk that they will not be fully paid off by the contracted date. It is, after all, not uncommon for customers to fall into arrears. As much as one half of the stock of trade credit in many countries is overdue at any one time (Rajan and Zingales, 1995; Schaffer, 1998).

Inter-firm payment disputes are particularly well suited for comparative purposes. For one, they tend to be relatively straightforward and easy to resolve since the contractual violations and, thus, injury to the creditor, can generally be determined quickly and objectively (Djankov et al., 2003). ${ }^{4}$ For another, they are among the most common types of commercial disagreements across a wide range of historical and geographic contexts (Kagan, 1984). In post-socialist Europe, inter-firm payment disputes have become a common feature of the economic landscape. Indeed, the patterns of both trade credit and inter-enterprise arrears that have arisen look like those 
observed in more mature institutional environments. Almost immediately after the fall of communist regimes and the dismantling of their managed economic systems, firms began extending trade credits to one another. Almost as quickly, they confronted the problem of overdue payments. Survey evidence from the early 1990s shows that deliveries to firms that fell into arrears would generally be stopped and that pre-payment was required from those for whom the capacity or willingness to pay at a later date was in doubt (Schaffer, 1998). In other words, firms in transition countries took very little time to learn the cost of unpaid bills and adapted their behavior accordingly. They understood, in short, that payment disputes were to be avoided.

When disputes have arisen, however, firms have been able to fall back on both private mechanisms as well as the public courts to work them out. Hendley and Murrell (2003) show that Romanian managers report that both bilateral relational mechanisms and the court system have been critical to preventing and resolving inter-firm disagreements. And Johnson et al. (2002a) implicitly confirm the same using firm-level responses from five post-socialist countries. ${ }^{5}$ Although the speed with which the region's court systems evolved to support commercial transactions has been impressive, their effectiveness has remained somewhat limited (Dietrich, 2000; Ramasastry, 2002). ${ }^{6}$ Comprehensive studies released by the World Bank noted that many judges lack the expertise to reach suitable decisions or fall prone to corruption at the hands of powerful actors (Dietrich, 2000; Hellman et al., 2003). ${ }^{7}$ Some courts, moreover, report being ill-equipped to enforce their rulings. ${ }^{8}$ A recent survey of legal experts in over one hundred countries helps put some of these difficulties into a broader comparative perspective. The time costs of using courts to resolve simple payment disputes in post-socialist countries substantially exceed the norm in many parts of the developing world. In Poland, a country judged to have one of the region's most advanced legal systems, the time needed to collect a bounced check is over four times the global average (Djankov, et al., 2003). ${ }^{9}$ Nevertheless, relative to the enormity of the task, progress in the region has been impressive (Dietrich, 2000). As we will show in what follows, as early as the mid-1990s, the legal system in Central European countries was being used regularly to resolve payment disputes and, judging from firms' actions and responses, was producing satisfactory results. Moreover, we will observe that public institutions have been complemented by private mechanisms that also have been developed to support market-based exchange. 
With respect to private mechanisms, we draw attention in this paper to the effect of membership in business associations - private, non-commercial organizations designed to promote the interests of members. While it has long been recognized that they may pursue rentseeking objectives that benefit their members to the net detriment of society (Smith, 1776; Olson, 1982), recent research has highlighted how, particularly in countries with weak states, business associations offer services that complement markets and create net social benefits. Some offer formal dispute resolution services and many enhance relational contracting by collecting and disseminating information on firms' reliability (Doner and Schneider, 2000; Macaulay, 1963; Woodruff, 1998). For some commentators, it has thus become natural to think of these associations as substitutes to the public court system (World Development Report 2002).

The relatively small literature on the impact of business associations in transition economies has not produced a clear consensus. Some present evidence that they help promote relational contracting (Greif and Kandel, 1995; Pyle, 2005; and Recanatini and Ryterman, 2001). Others, however, have generally downplayed their role in this regard or have suggested that their role in directly adjudicating disputes is minimal (Broadman et al., 2004; Hendley, 2001; Hendley and Murrell, 2003; McMillan and Woodruff, 1999a). ${ }^{10}$ The reasons for the apparent disagreement are not altogether clear. Some may relate to the way in which different survey questions are phrased; some may be due to cross-country differences in institutional contexts. What is clear, however, is that the contribution of these organizations to reducing the transaction costs of their members remains an open question.

\section{Data}

In 1997, the European Bank for Reconstruction and Development sponsored a survey designed to study the difficulties confronting small and medium-sized enterprise development in transition countries. Roughly one thousand manufacturing firms in Poland, Slovakia and Romania participated. ${ }^{11}$ The lead investigators generated several noteworthy papers before placing the data in the public domain (Johnson, Kaufmann, McMillan and Woodruff, 2000; Johnson et al., 2002a; Johnson et al., 2002b).

In general, the average firm in the survey does not vary greatly across the countries. As shown in Table 1, in each of the three countries, it operates with slightly under a hundred employees and faces a not insignificant amount of competition. Most of the firms are owned 
privately by nationals of the country in which they are located; indeed, no more than five percent of the respondents have in excess of one-quarter state or foreign ownership. On average, these firms show a fair amount of turnover in their customer base, with roughly one-fifth of customers being new in the past year. Only in terms of performance indicators do we observe much difference across countries. Well over $90 \%$ of the respondents in Poland and Romania report being profitable in 1996; whereas in Slovakia, performance appears not to have been quite as impressive.

\section{[TABLE 1]}

The EBRD survey addressed both experience with standard contracting problems as well as general attitudes toward mechanisms for enforcing agreements and resolving disputes. As shown in Table 2, over three-quarters of respondents had had a customer fail to pay for a delivery. And roughly one-quarter had had problems with a supplier that refused either to accept the return of defective merchandise or to provide monetary compensation. We should bear in mind that the quality of a country's legal institutions may have an ambiguous relationship to these indicators (Bigsten et al., 2000). An effective court system may deter opportunistic breach of contract in which case we would expect an inverse relationship between incidence of payment disputes and the effectiveness of legal institutions. On the other hand, a more effective legal system may embolden firms to engage in transactions that might otherwise have been avoided; for instance, they might be more willing to extend trade credit to a relatively new customer.

Perhaps a better indicator of the effectiveness of a country's legal system is the degree to which courts are considered capable of upholding laws and supporting private contracts. Over three-quarters of surveyed firms in these three countries report that the court system can enforce an agreement with a business partner. And as Johnson et al. (2002) demonstrated with this same database, this faith in courts is associated with a greater willingness to establish new trade relationships. By extension, we would expect such faith to affect the use of courts when contracts are breached, particularly if alternative mechanisms are not considered viable. Indeed, relative to other public institutions as well as private contract enforcers, the data show that these still nascent and imperfect courts have established themselves as the most widely trusted enforcement mechanism. Even so, however, a non-trivial percentage of surveyed enterprises, roughly one-sixth, considers no institution capable of fulfilling this roll, and a similar number 
report never having appealed to any third party to resolve disputes even though over four-fifths of firms expressed that they had experienced at least one of two standard types of contracting problems noted in Table 2. ${ }^{12}$

\section{[TABLE 2]}

In addition to these general responses regarding their history with commercial disputes and their trust in and use of various enforcement mechanisms, survey respondents answered questions specifically related to the most recent payment dispute in which they were involved. We are thus able to assess the firm-level and relationship-specific correlates of how particular disputes evolve in a well-defined context. For the sake of standardization, we focus exclusively on those disputes that occurred in the two-year period prior to the survey, meaning that we drop from the analysis those firms whose most recent dispute occurred before 1995. Moreover, we exclude firms who report on a payment disagreement with a supplier.

Considering the large sample size, we have at our disposal a good deal of information about the respondent, the trade partner and their interaction. The summary data for the disputes, broken down by country, are presented in Table $3 \mathrm{~A} .{ }^{13}$ As we observe, roughly $80 \%$ of disputes occurred with private enterprises. Roughly $60 \%$ occurred with partners located in or close to the same city as the respondent, while just over 5\% were with firms located in other countries. On average, the firms involved had been business partners for eighteen months. We should note here that we do not have information on the monetary amount involved in the dispute. Since this may be related to behavior at successive stages of the dispute, we should be cautious in our interpretation of the regression results. That is, since the size of the dispute may be associated with the choice of resolution mechanisms, the fraction of the debt recovered and the decision to continue transacting ex post, we should evaluate our results in light of a possible omitted variable bias.

\section{[TABLE 3A]}

In each country, courts became involved in more than one-quarter but less than one-half of the reported disputes. In Poland, the rate of court use exceeded that in Romania by a factor of two, a finding consistent with the former's higher ranking in a survey of legal system effectiveness conducted at the same time (Ramasastry, 2002). Firms in the region most frequently reported not having involved any third party, public or private, to resolve the dispute. 
Only a very small minority report having used private agencies, either alone or in conjunction with the courts.

In roughly one-sixth of the cases, the dispute concluded with respondents collecting nothing and writing off the customer's debt completely. Half of the disputes ended with a partial recovery. And in the remainder, the respondents recovered the full amount that they were owed. For reasons that are not entirely clear, these data suggest that disputes in Romania were resolved in the supplier's favor more frequently than in Slovakia and Poland. Finally, we observe that business partnerships survived a payment dispute in $36.7 \%$ of the cases, with the rates in Slovakia and Romania measuring roughly twice that in Poland.

\section{Litigation}

A payment dispute may be thought of as a multi-stage process that may or may not proceed through the court system (Felstiner et al., 1980-81; Hendley, 2001). After failing to receive payment in the contracted time frame, the seller will, almost always, make an appeal to the delinquent party. ${ }^{14}$ The nature of this exchange can vary greatly. The seller can provide gentle reminders or make menacing threats; or the two parties may immediately enter negotiations to work out a new repayment schedule; or they may find some other alternative, but mutually satisfactory, resolution. The seller might also choose to involve other private parties somehow, either to exert pressure on the buyer or to assist in some other way to resolve the dispute. For instance, the seller may damage the buyer's reputation by spreading information about the problem among other firms. Alternatively, private dispute resolution institutions could be called upon to provide mediation services. Whatever the exact mechanism, this preliminary step is distinguished by communications that remain outside of publicly sponsored channels.

Purely private mechanisms, however, may not produce a satisfactory outcome from the seller's standpoint. If this is the case, the grievance will either be dropped or transformed into a legal claim in which case the public court system will be asked to render a judgment. As a general rule, few business disputes actually end up in litigation. Most conclude at an earlier stage with the two parties reaching a mutually satisfactory agreement or the aggrieved dropping the claim. This is as true for countries with mature public institutions (Cooter and Rubinfeld, 1989; Macaulay, 1963; Macaulay, 1977) as for those without them (Bigsten et al., 2000; Hendley, 2004). After all, the costs of going to court are rarely trivial. Often, these costs provide the 
disputants with good reason to find alternative ways to resolve their differences. In addition to explicit monetary outlays, which may include lawyers' bills and filing fees, the commitment of time to a court case can divert resources from a firm's core, income-generating activities (Priest and Klein, 1984). ${ }^{15}$ Indeed, the simplest commercial cases, like the recovery of a bounced check, can take several months to resolve even in well-functioning institutional environments (Djankov, et al., 2003).

Additionally, a dispute may be kept out of the courts because of a lack of faith in the legal system's effectiveness. Judges, for instance, may lack the expertise and experience to reach suitable decisions, thus making the outcome of litigation less predictable (Dietrich, 2000). ${ }^{16} \mathrm{Or}$ they might be prone to capture by powerful actors (Broadman et al., 2004; Hellman et al., 2003; Dietrich, 2000). Or courts simply may be ill equipped to enforce their rulings. ${ }^{17}$ As we observed already, such doubts in the legal system are not altogether uncommon in the post-socialist context.

Given the discussion to this point, we would expect that the decision to take a dispute to court would hinge upon the macro-institutional environment - most notably, the effectiveness and accessibility of the court system. But the cost-benefit calculus, however, is just as likely to be influenced by more micro-level factors. The same firm may find different mechanisms preferable in different circumstances depending upon the characteristics of the other party and the nature of their shared relationship. For instance, since mutual goodwill and trust can often only develop in a relationship with time, longer-term business partners may have a greater capacity to cooperate and thus be more likely to settle disagreements amicably and outside of court (Macaulay, 1963; Hendley, 2004).

Geographic distance between trade partners may also influence the decision to resolve a dispute through the court system. Trans-national discontinuities in legal systems, for instance, may make a supplier less likely to file suit against a delinquent customer based in another country (Anderson and Marcouiller, 2002; Anderson and van Wincoop, 2004; Rodrik, 2000). Local courts may be unwilling and international courts unable to enforce agreements reached between firms from different countries. Indeed, some support for this notion is observable in Table 3B; the survey data show that payment disputes with foreign customers have been less likely to be resolved through the court system. 


\section{[TABLE 3B]}

Inside a single country, however, we have less in the way of theory or prior research to guide the generation of hypotheses. If intra-country jurisdictional boundaries raise the expected costs of enforcement, it might be natural to suspect that disincentives to litigate decrease with the distance between firms. On the other hand, the closer two parties are in relationship to one another, the greater the potential role of alternative relational mechanisms for resolving disputes (North, 1990). With geographic proximity, that is, face-to-face negotiations may be less costly and reputational sanctions may carry greater weight. Thus, all else equal, the relative value of public mechanisms will not be as great. In Table 3B, we observe that courts are more apt to be involved when disputants are in the same country but not from the same city. This is consistent with the proposition noted above that trade partners in close proximity to one another have a richer array of options for resolving a dispute.

In transition countries, business associations have been shown to provide the basis for relational contracting (Greif and Kandel, 1995) by giving members access to a network of firms through which the behavioral histories of their trade partners can be transmitted. Pyle (2005) shows that the relative importance of business associations in channeling inter-firm information flows is greater when the offending and the aggrieved parties are located in different regions. Given their role in providing informational services that can potentially substitute for the legal system, we might expect membership in a business association to be negatively associated with taking a dispute to court (World Development Report 2002). On the other hand, business associations have been known to disseminate information about the legal system to their constituents (Doner and Schneider, 2000). In a rapidly changing institutional environment, there may well be economies (especially, to small and medium-sized enterprises) to a collectively sponsored organization that offers constituents legal consulting services. Indeed, both anecdotal and survey evidence suggest that business associations in post-socialist countries do serve exactly this function. ${ }^{18}$ If this is the case, then business association membership, all else equal, may be positively associated with use of the courts. Moreover, Frye (2002) has shown with Russian data that firms belonging to business associations are more successful in influencing legislation, particularly at the regional and local levels. Such influence may well extend to commercial courts. Indeed, Hellman et al. (2003) report that roughly one-fifth of firms believe that the sale of arbitration (commercial) court decisions in Poland, Romania and Slovakia has a 
"significant or very significant impact on their business." Given all these considerations, it is not clear ex ante whether business association membership should positively or negatively influence the decision to take a dispute to court.

\section{[TABLE 3C]}

Larger firms may be more willing to absorb the fixed costs associated with bringing a case to court (Broadman et al., 2004). ${ }^{19}$ There is evidence, for instance, that the confusing legal environment of the transition is more burdensome for smaller enterprises that do not have inhouse counsel or have fewer resources with which to "capture" judges (Dietrich, 2000; Hellman et al., 2003). ${ }^{20}$ What is more, state ownership may increase the probability that a firm receives a favorable hearing and, with it, the attractiveness of going to court (Broadman et al., 2004). ${ }^{21}$ And it has been argued in developing countries that older firms possess greater familiarity with, and thus a greater disposition to use, formal legal institutions (Bigsten et al., 2000). However, it is not inconceivable that age, as well, brings greater appreciation for informal resolution mechanisms. Some, that is, have suggested that the primary beneficiaries of well-functioning courts are newer firms whose managers may not have well-established business or social connections and thus may find it more difficult to settle out of court (Hendley et al., 1997; McMillan and Woodruff, 1999a; McMillan and Woodruff, 1999b).

On the basis of case study evidence from Russia, Hendley (2001) argues that a high degree of customer turnover correlates with greater rates of litigation since the cost of damaging a relationship through litigation is less if the search costs for new customers are comparatively low. ${ }^{22}$ Moreover, it is possible that a firm taking on more new customers may receive greater value from a reputation as a tough bargainer and would, thus, be more likely to take disputes to court (Farmer and Pecorino, 1998).

The legal studies literature suggests several other potential firm-specific correlates of litigation as the recourse for a commercial dispute. Cheit and Gersen (2000) note that firms in expanding industries are less likely to use litigation because the short-term value of winning a case in court will be relatively smaller when compared to the returns on resources invested elsewhere. Although, this conclusion was reached on the basis of sector-level evidence, the same logic of opportunity costs could be applied to individual enterprises. That is, investing time and 
money in litigation will be more costly for firms whose core business is generating a higher return. And Kenworthy et al. (1996) argue that lower rates of market concentration are associated with lower rates of litigation. Firms that face a number of competitors will be more likely to litigate since they "can less easily afford to forgo opportunities for immediate gain, and their room for maneuver, and ability to sustain the cost of constructing and applying alternative sanctions are reduced.”

Considering our discussion to this point, we now explore the determinates of using the court system to resolve a dispute in the following probit regression:

$\operatorname{Pr}\left(y_{i}=1\right)=\operatorname{Pr}\left(\beta_{0}+\beta_{1} F_{i}+\beta_{2} R_{i}+\beta_{3} M_{i}+\varepsilon_{i}>0\right)=\Phi\left(\beta_{0}+\beta_{1} F_{i}+\beta_{2} R_{i}+\beta_{3} M_{i}\right)$,

where $y_{i}=1$ if the dispute went before the courts; ${ }^{23} F_{i}$ represents a vector of firm-specific variables, which include the creditor's membership in a business association; $R_{i}$ is a vector of variables describing the characteristics of the relationship between the respondent and the customer, which include their geographic proximity; $\mathrm{M}_{\mathrm{i}}$ represents a vector of macro-level variables, which include country and year-of-dispute controls; and $\Phi(\cdot)$ is the normal cumulative distribution function. ${ }^{24}$

Table 4A presents evidence that the use of courts to resolve payment disputes is a function of both the respondent's membership in a formal business network and the geographic relationship between itself and the offending client. ${ }^{25}$ In the specification presented in column 1, we observe that relative to the instance in which the delinquent customer is located in the same city, a firm is roughly thirteen percentage points more likely to take a dispute to court if the defendant is located near, but not in, the same city. This relationship is shown to be even stronger when we restrict the disputes just to the subset that comprises parties that are located either in the same city or are otherwise relatively close to each other (see column 3 ).

Column 2 reveals that relative to a customer located in the same city, the likelihood of taking a delinquent client to court is fifteen percentage points greater if that client is located elsewhere in the country. However, this is only the case if the respondent is not a member of a business association. In light of earlier research suggesting that business associations in transition countries enhance existing relational information flows with respect to non-local, domestic clients (Pyle, 2005), column 2 adds an interaction term to the base regression in column 1. This new variable takes on the value of one if the respondent is a member of a business 
association whose most recent payment dispute occurred with a firm located in the same country but in a region other than the respondent's. By its inclusion, we are presented with evidence suggesting that for non-association members, greater distance between disputants within the same country is associated with an increased probability of taking a dispute to court. But for association members, a problematic client located outside one's locale is no more likely to be taken to court than one located in one's locale. The negative and statistically significant association of the interaction term and litigating the dispute roughly cancels out the direct effect of the client being "located elsewhere in the country." This evidence thus provides support for the proposition that business associations offer services that substitute for the court system with respect to distant, domestic relationships.

However, with respect to a dispute occurring between firms located in the same region (i.e., the two are in the same city or are otherwise close by), the evidence suggests that associations may actually complement the formal legal system (see column 3). Association members, that is, are roughly fifteen percentage points more likely to use the courts - an association that is significant at the $5 \%$ level. This finding contradicts the conventional wisdom that, with respect to contract disputes, business organizations provide services that solely substitute for public enforcement mechanisms (World Development Report 2002). How can this then be explained?

Since we already possess evidence that associations contribute to inter-firm information flows regarding contract violators (Macaulay, 1963; Doner and Schneider, 2000; Pyle, 2005; Woodruff, 1998), it is not un-natural to suppose that they also enhance other types of information dissemination, including information regarding how to access and effectively utilize the court system. Indeed, as we noted above, both anecdotal and survey evidence from the region suggests that this is the case. An alternative explanation for the positive association between membership in a business organization and use of the courts could be that associations facilitate unjust influence over the legal process. Although our data do not allow us to definitively eliminate this explanation, we should note that our sample is not composed of those types of enterprises that have been shown to be capable of successfully influencing public actors in post-socialist countries - i.e., large, state-owned firms with a significant degree of market power (Hellman et al., 2003). ${ }^{26}$ Rather, the sample here is made up of small and medium-sized private enterprises that face substantial competition. 
The evidence that greater distance between disputants raises the demand for courtsupplied dispute resolution, ceteris paribus, is consistent with the suggestion of North (1990) that outside localized settings, the relative value of more informal contracting mechanisms falls. Certain types of relational contracting weaken across geographic space; periodic hounding of delinquent clients, for instance, may be a more costly or less effective strategy if they are in another town. The relationship between distance and use of courts, however, does not apply to disputes across national boundaries. International borders clearly diminish the net benefits associated with court-based contract enforcement (Anderson and Marcouiller, 2002; Anderson and van Wincoop, 2004; Rodrik, 2000).

Finally, we observe that larger firms are much more likely to use the court system to resolve disputes, a result that mirrors findings from a recent study of African manufacturers (Bigsten et al., 2000). We also observe that controlling for the overall size of a firm's customer base, having a larger number of new clients makes a firm more likely to resolve a dispute through the court system. To the extent that a newer customer is more apt to be influenced by a signal of a "willingness to go to court," the value of the signal will be greater the larger the number of new customers. The positive association here could also be explained by the lesser value attached to specific relationships, and thus less interest in working toward a cooperative solution, when new customers are easily found. Litigation, that is, may be less costly to suppliers who have an easier time finding clients. ${ }^{27}$

\section{Debt Recovery and Relationship Survival}

The selection of the resolution mechanism does not put an end to matters. A court finding that the defendant is obligated to pay or a private agreement establishing a repayment schedule brings the dispute into the settlement phase. The seller then either passively awaits repayment or actively pursues the buyer through informal or formal means. Finally, after the settlement has been implemented, the two parties decide whether to maintain their relationship. Although a decision to terminate it need not relate directly to the dispute, it is entirely possible that the seller

no longer finds the buyer trustworthy or that the two no longer share the mutual goodwill necessary to engage in future transactions.

The determinates of the transaction costs related to the incomplete recovery of a debt and the potential need to search for and screen new partners have received almost no attention in the 
economics literature. However, it is not unreasonable to believe that they affect the firm-level calculus as to the costs of doing business when the probability of a dispute is not insignificant. From the perspective of a firm that may be in the position of being a claimant in a future payment dispute, the greater the perceived probability that such disputes can be resolved successfully and amicably, the less threat they pose to the expansion of market relations. If monies owed can eventually be recovered and/or if the search costs for new partners (associated with a severed relationship) can be avoided, the expected costs of a dispute will be less and firms will be emboldened to enter a wider array of arms-length transactions.

\subsection{Debt Recovery}

As with the selection of the appropriate mechanism to resolve the dispute, we anticipate that the recovery of the amounts owed will be influenced by both the geography of the relationship and the supplier's access to an organization that expands access to mechanisms for relational contracting. Specifically, we anticipate that greater geographic distance between parties will decrease the percentage of the disputed amount that is recovered. With increased distance, the supplier's costs of collecting a fixed amount are likely to rise. And the customer's costs of reneging, specifically with respect to reputational damage, are likely to fall. Indeed, this relationship between the degree of payment recovery and geographic distance initially appears to be confirmed by evidence presented in Table 3B. Relative to a debtor abroad, nearly twice the share of arrears are paid off in full when the customer is located in the same city. And for firms located somewhere outside the city of the respondent, the rate of complete write offs is roughly twice that for local debtors.

We would also expect that if business associations do provide informational and consulting services that help resolve disputes, the members' ability to recover debts should, ceteris paribus, be superior to non-members. And indeed, in Table 3C, we observe that members are more apt to recover their loss in full and less apt to write off the debt completely.

In addition to the geographic and institutional determinants of the degree of payment recovery, it is not unreasonable to hypothesize that the variables presumed to be associated with litigating a dispute would affect the willingness and ability of a claimant to recover an unpaid debt. We thus explore the effects of its size, age, ownership type, recent financial success as well as the nature of the market in which it operates; on the customer's side, we explore the impact of 
its ownership type and the length of its relationship with the claimant. In short, we expect that the supplier's effort and ability to recover the payment as well as the customer's willingness and ability to settle the matter amicably will depend on firm and relationship-specific characteristics, macro-institutional variables, and lastly, the mechanism chosen to resolve the dispute. The inclusion of a dummy variable for whether or not the dispute had been taken to court is likely to be a good proxy for the dispute's severity (Macauley, 1977; Williamson, 1996).

Considering our discussion to this point, we estimate the following in an ordered probit framework:

$\operatorname{Pr}\left(\mathrm{y}_{\mathrm{i}}=1\right)=\Phi\left(-\left(\beta_{0}+\beta_{1} \mathrm{~F}_{\mathrm{i}}+\beta_{2} \mathrm{R}_{\mathrm{i}}+\beta_{3} \mathrm{M}_{\mathrm{i}}+\beta_{4} \mathrm{E}_{\mathrm{i}}\right)\right.$,

$\operatorname{Pr}\left(\mathrm{y}_{\mathrm{i}}=2\right)=\Phi\left(\theta_{1}-\left(\beta_{0}+\beta_{1} \mathrm{~F}_{\mathrm{i}}+\beta_{2} \mathrm{R}_{\mathrm{i}}+\beta_{3} \mathrm{M}_{\mathrm{i}}+\beta_{4} \mathrm{E}_{\mathrm{i}}\right)\right)-\Phi\left(-\left(\beta_{0}+\beta_{1} \mathrm{~F}_{\mathrm{i}}+\beta_{2} \mathrm{R}_{\mathrm{i}}+\beta_{3} \mathrm{M}_{\mathrm{i}}+\beta_{4} \mathrm{E}_{\mathrm{i}}\right)\right)$,

$\operatorname{Pr}\left(\mathrm{y}_{\mathrm{i}}=3\right)=1-\Phi\left(\theta_{1}-\left(\beta_{0}+\beta_{1} \mathrm{~F}_{\mathrm{i}}+\beta_{2} \mathrm{R}_{\mathrm{i}}+\beta_{3} \mathrm{M}_{\mathrm{i}}+\beta_{4} \mathrm{E}_{\mathrm{i}}\right)\right)$,

where $y_{i}=1$ if the debt was written off completely, $y_{i}=2$ if the debt was recovered in part, and $y_{i}$ $=3$ if the debt was recovered in full; $F_{i}$ represents a vector of firm-specific variables; $R_{i}$ is a vector of variables describing the characteristics of the relationship between the respondent and the customer; $\mathrm{M}_{\mathrm{i}}$ represents a vector of macro-level variables, which include country and yearof-dispute controls; and $\mathrm{E}_{\mathrm{i}}$ is a vector of variables capturing the evolution of the dispute to this stage (i.e., a control for whether or not it was taken to court); $\theta_{1}$ (with $\theta_{1}>0$ ) is a threshold value for an unobserved latent variable measuring the respondent's willingness and ability to recover the amount due; and $\Phi(\cdot)$ is the normal cumulative distribution function.

Table 4B presents evidence that the degree of payment recovery is a function of both the respondent's membership in a formal business network and the geographic relationship between itself and the offending client. Regardless of whether we consider the full sample or the subsample of intra-country disputes, we observe that business association members are more likely to receive a larger share of the debt owed by a customer. ${ }^{28}$ Trade association members are roughly ten percentage points more likely to be compensated in full and six percentage points less likely to write off the debts completely; both effects are significant at the $5 \%$ level.

Several mechanisms could explain this positive association between business association membership and the degree of payment recovery. First, some associations enhance existing informal flows of information among firms and thus provide constituents with a mechanism that 
enhances reputation-based sanctions, which may increase customers' incentive to re-pay. Second, some associations provide advice as to what constitutes best practices regarding dispute resolution that may raise the net returns from efforts to reach a favorable settlement. In both respects, business organizations can be thought of as serving as nodes within a network of firms, collecting and disseminating information produced by members' experiences. ${ }^{29}$

As noted earlier, a potential alternative to the association as informational node explanation is the association as influence peddler. Because business association members in the post-socialist world have been shown to have greater influence than non-members over public institutions (Frye, 2002), we include a control for the interaction of association membership and the dispute having been taken to the court (see columns 3 and 4 ).$^{30}$ If the positive association between payment recovery and membership in a business organization is due to members' undue influence over court decisions, we might expect the sign on this interaction term to be positive and significant and, possibly, the coefficient on the business association dummy to lose its statistical significance. However, columns 3 and 4 do not offer support for this political leverage explanation. The interaction term is not associated with payment recovery in a statistically significant manner and the coefficient on the association dummy variable remains positive and statistically significant. That is, association members whose disputes were not taken to court recovered their debts with success roughly equal to those that litigated.

Relative to disputes with foreigners, claimants seeking to settle debts with other firms in their country are much more likely to be successful. For instance, relative to a dispute with a firm abroad, a claimant whose client is in the same city is nineteen percentage points less likely to write off a debt completely and 37 percentage points more likely to be fully compensated - with both effects significant at the $1 \%$ level. This finding confirms earlier work suggesting that the costs of contract enforcement are an important component of the "border effects" that underlie the sub-optimal volume of trade flows (Anderson and Marcouiller, 2002; Anderson and van Wincoop, 2004). Although the relative effects of distance are less pronounced within a country, we do observe in column 2 that relative to a client that is abroad, debts with firms are more likely to be settled in full the closer the two firms are to one another.

In addition to the geographic and business institution effects, we observe that firms that are more than one-quarter owned by the state have more success in recovering their debts. A 
state-owned firm may be able to bring more pressure to bear on a delinquent customer than another firm that is otherwise similar. Interestingly, we do not observe a similar state-ownership bias with respect to the customer. Indebted state firms, that is, are no less likely than non-state firms to pay off the amount in dispute. Perhaps the effect of increased bargaining power is negated, in part, by softer budget constraints; state-owned firms, that is, may face less of a cost for re-paying a given amount of debt.

Less profitable firms are more likely to receive a greater percentage of a disputed payment. What perhaps initially seems counter-intuitive can perhaps best be understood as a function of the opportunity cost of diverting time and other scarce resources away from profit generating activities to debt collection efforts, the outcome of which may be highly uncertain (Cheit and Gersen, 2000; Priest and Klein, 1984). ${ }^{31}$ Lastly, we observe the particularly strong negative association between use of the court system and an outcome that is satisfactory to the respondent, a finding that strongly suggests that only the most difficult cases are brought before the courts for resolution.

\subsection{Relationship Survival}

Over sixty percent of the respondents to the survey reported that they no longer did business with the offending client (see Table 3A). The dispute itself may have been responsible by providing either (or both) firm(s) with information about the other's intentions or capabilities, which then tipped the cost-benefit calculus in favor of termination. ${ }^{32}$ The supplier, for instance, may have revised a prior belief about the client's ability and/or willingness to pay bills on time. New information need not have been generated, however, for the dispute to end the relationship. Simply by eroding their shared stock of goodwill and trust, the firms may have recognized that the costs of a continued relationship would outweigh the expected benefits.

Termination of the relationship may impose costs that the two firms might prefer to avoid. Resources potentially needed to search for and screen new trade partners, that is, could be deployed elsewhere. All else equal, a dispute that does not lead to a relationship's dissolution imposes less of a social cost. For this reason, in particular, we are interested in the relevant determinates of a relationship's durability. As above, we highlight the influence of both interfirm distance and business association membership. With respect to the former, we presume that greater proximity of the parties increases the ease of reaching an amicable settlement, both 
because the costs of communication decline and because the mechanisms for community-based sanctioning strengthen. The potential impact of business association membership, however, is not altogether obvious. On the one hand, members of business associations may be more willing to give up on an existing relationship because an association's information services may reduce the search costs for a new client. On the other hand, associations may provide members with access to information and other resources that increase the probability of reaching an amicable settlement.

In addition to the geographic and institutional determinants, it is reasonable to believe that the cost to the two firms of terminating the relationship will be a function of the respective parties' outside options. The more competitors the supplier has, the lower the cost to the client of severing the relationship; and the more potential clients the supplier has, the lower its cost of termination.

We thus estimate the following probit regression:

$\operatorname{Pr}\left(y_{i}=1\right)=\operatorname{Pr}\left(\beta_{0}+\beta_{1} F_{i}+\beta_{2} R_{i}+\beta_{3} M_{i}+\varepsilon_{i}>0\right)=\Phi\left(\beta_{0}+\beta_{1} F_{i}+\beta_{2} R_{i}+\beta_{3} M_{i}+\beta_{4} E_{i}\right)$,

where $y_{i}=1$ if the relationship endures; $F_{i}$ represents a vector of firm-specific variables, which include controls for both firms' outside options and the respondent's membership in a business association; $R_{i}$ is a vector of variables describing the characteristics of the relationship between the respondent and the customer, which include their geographic proximity; $\mathrm{M}_{\mathrm{i}}$ represents a vector of macro-level variables, which include country and year-of-dispute controls; and $\mathrm{E}_{\mathrm{i}}$ is a vector of variables capturing how the dispute has evolved - i.e., whether or not it was taken to court as well as the degree to which the creditor was successful in recovering the money.

Business association membership, again, proves to be associated with behavior at a critical stage in the evolution of a commercial dispute. Table $4 \mathrm{C}$ demonstrates that when controlling for behaviors in previous stages, member suppliers are over ten percent more likely to continue transacting with customers with whom they had experienced a payment dispute. We can only speculate as to the mechanisms at work here. But given what we know about associations increasing the flow of relational information among firms, one possible explanation is that by having access to a network of firms (and the reputation-related penalties that it can impose), a supplier is more likely to face a compliant and cooperative client in repayment 
negotiations. As such, there is a decreased probability that the dispute erodes the goodwill shared between the firms.

Table 4C also demonstrates again geography's important role. In the sample with all disputes (see column 1), we observe that firms whose partners are located "elsewhere in the country" are fifteen percentage points less likely than those with local partners (i.e., those that are based either in or near the city where the supplier is located) to maintain the relationship in the dispute's aftermath. In column 2, we see that this relationship appears to be driven by disputes that are decided in the courts. Court-mediated disputes with non-local firms located "elsewhere in the country" are nearly 27 percentage points more likely to end in the relationship's dissolution than those with local clients; this interaction effect is statistically significant at the $1 \%$ level.

We also observe that relationships are less likely to survive when the supplier faces more local competition. In other words, when their clients have more outside options, the forces holding the relationship together will not be as strong. As anticipated, there is a negative relationship between the number of new clients a supplier has and the survival of the relationship. However, it is not statistically significant. We also observe that state-owned customers that had fallen into arrears are more likely to be retained than their private counterparts, an effect that holds at the 5\% level. As before, we may be picking up evidence that within the context of a dispute, state actors may be able to bring resources to bear that others cannot. In this case, state officials might be in a position to pressure suppliers to continue making deliveries. ${ }^{33}$ Finally, we observe that the prior evolution of the dispute has an impact on its survival. Both a higher degree of payment recovery and out-of-court resolution are strongly and positively associated with the dispute not leading to the relationship's dissolution.

\section{Conclusion}

By focusing on firms in three former socialist countries, we are able to observe the response to contractual disputes at a particularly critical stage of economic development. In the early to mid-1990s, many managers in post-socialist Europe were still learning about marketbased exchange. It is natural to suspect that these initial experiences conditioned their thinking about the costs of transacting. And these first assessments could be expected to have a lasting influence on the development of markets. If procedures for resolving disputes were viewed as 
excessively burdensome or if amicable settlements were considered uncommon, the fear of broken promises and bitter disputes could seriously impede the subsequent development of markets. But if disagreements could be resolved at little cost and in a mutually satisfactory manner, firms would be more likely to widen the scope of their transactions with confidence.

The evidence presented here suggests that one important lesson learned in the early transition is that the transaction costs associated with a commercial dispute increase if trade partners are located at a distance from oneself. Our evidence also points to the conclusion that the cost of a given dispute can be mitigated by membership in a non-profit business organization. We should be careful not to draw from this finding that business association activity is net welfare enhancing. We have no grounds, that is, to dismiss the rent-seeking concerns that Smith (1976) and Olson (1982) expressed with respect to organized business. Some associations, however, do appear to offer valuable market-supporting services by complementing the domestic court system and reducing the damage done by payment disputes. These findings suggest that future research should explore why not all firms join these associations and why only some associations provide such services. 


\begin{tabular}{lcccc}
\hline \multicolumn{4}{c}{ Table 1. Summary } & Data on Respondents \\
\hline & All & Poland & Slovakia & Romania \\
\hline Employees & 58.7 & 63.0 & 57.0 & 56.4 \\
Customers & 97.7 & 99.7 & 86.0 & 107.1 \\
Customers new in past year & 17.4 & 17.8 & 15.1 & 19.4 \\
Like firms in same city & 8.7 & 10.7 & 6.5 & 8.8 \\
State owned (\%) & 4.9 & 7.3 & 2.3 & 5.3 \\
Foreign owned (\%) & 3.7 & 3.6 & 6.2 & 1.3 \\
Business association members (\%) & 34.7 & 28.9 & 31.5 & 44.2 \\
Profits as percent of sales in 1996 (\%) & & & & \\
Negative & 7.9 & 4.8 & 18.2 & 1.3 \\
$0 \%$ & 4.6 & 2.1 & 11.0 & 1.3 \\
$1-10 \%$ & 47.7 & 54.6 & 50.3 & 39.1 \\
$11-20 \%$ & 29.6 & 28.3 & 14.0 & 45.0 \\
$21-40 \%$ & 9.5 & 9.9 & 6.5 & 11.9 \\
$>40 \%$ & 0.7 & 0.3 & 0.0 & 1.6 \\
\hline
\end{tabular}


Table 2. Enforcing Agreements and Resolving Disputes in Eastern Europe

All Poland Slovakia Romania

Has a customer ever failed to pay for product after delivery? (\% responding, "yes")

Number of observations

$\begin{array}{llll}77.4 & 76.2 \quad 81.5 & 74.5\end{array}$

$932 \quad 303 \quad 308 \quad 321$

Has a supplier ever refused to accept return of defective merchandise or to refund money for merchandise returned because of low quality? (\% responding, "yes")

Number of observations

$29.9 \quad 18.5 \quad 37.3 \quad 33.4$

$931 \quad 303 \quad 308 \quad 320$

Who can enforce agreement with a business partner? court

$\begin{array}{cccc}76.1 & 72.9 & 67.9 & 86.9 \\ 4.2 & 2.7 & 9.4 & 1.2 \\ 4.5 & 7.3 & 4.9 & 1.6 \\ 8.9 & 8.6 & 12.7 & 5.6 \\ 16.7 & 23.8 & 20.6 & 6.2 \\ 932 & 303 & 308 & 321\end{array}$

If you had contract disputes in the past have you resolved them without third party involvement?

\begin{tabular}{lcccc} 
never & 17.2 & 26.4 & 20.4 & 4.9 \\
sometimes $(<25 \%)$ & 17.0 & 13.9 & 21.1 & 15.9 \\
often $(25 \%<$ and $<75 \%)$ & 4.7 & 3.7 & 5.8 & 4.6 \\
almost always $(>75 \%)$ & 14.9 & 11.4 & 20.4 & 12.7 \\
always & 46.2 & 44.7 & 32.3 & 62.0 \\
Number of observations & 851 & 273 & 294 & 284 \\
\hline
\end{tabular}


Table 3A. Most Recent Payment Dispute with Customer

\begin{tabular}{|c|c|c|c|c|}
\hline & All & Poland & Slovakia & Romania \\
\hline \multicolumn{5}{|l|}{ Ownership type of customer } \\
\hline state (or mixed) enterprise & 20.6 & 22.7 & 12.6 & 73.6 \\
\hline private enterprise & 79.4 & 77.4 & 87.4 & 26.4 \\
\hline Number of observations & 573 & 181 & 191 & 201 \\
\hline \multicolumn{5}{|l|}{ Location of customer } \\
\hline in same city & 35.4 & 38.4 & 25.8 & 41.8 \\
\hline close to city & 23.2 & 22.2 & 25.3 & 22.2 \\
\hline elsewhere in country & 36.3 & 36.2 & 39.7 & 33.0 \\
\hline Abroad & 5.2 & 3.2 & 9.3 & 3.0 \\
\hline Number of observations & 582 & 185 & 194 & 203 \\
\hline \multicolumn{5}{|l|}{ Which organization(s) assisted? } \\
\hline Court & 36.2 & 48.6 & 33.7 & 27.6 \\
\hline private (formal or informal) agency & 4.3 & 6.9 & 5.4 & 1.0 \\
\hline court and private agency & 1.1 & 1.1 & 2.1 & 0.0 \\
\hline no one & 58.4 & 43.4 & 58.8 & 71.4 \\
\hline Number of observations & 558 & 175 & 187 & 196 \\
\hline \multicolumn{5}{|l|}{ What was the final outcome? } \\
\hline wrote off debt completely & 16.1 & 23.6 & 10.8 & 14.4 \\
\hline negotiated partial settlement & 49.3 & 48.3 & 62.7 & 37.8 \\
\hline recovered loss in full & 34.6 & 28.2 & 26.5 & 47.8 \\
\hline Number of observations & 560 & 174 & 185 & 201 \\
\hline Is firm still a customer? (\% responding, “yes") & 36.7 & 21.1 & 45.3 & 42.9 \\
\hline Number of observations & 580 & 185 & 192 & 203 \\
\hline
\end{tabular}


Table 3B. Most Recent Payment Dispute with Customer

\begin{tabular}{|c|c|c|c|c|}
\hline & Same city & $\begin{array}{l}\text { Near, not in } \\
\text { same city }\end{array}$ & $\begin{array}{c}\text { Elsewhere in } \\
\text { country }\end{array}$ & Abroad \\
\hline \multicolumn{5}{|l|}{ Which organization(s) assisted? } \\
\hline court & 30.5 & 42.7 & 39.2 & 24.1 \\
\hline private (formal or informal) agency & 4.0 & 2.4 & 3.9 & 17.2 \\
\hline court and private agency & 0.5 & 2.4 & 0.5 & 3.5 \\
\hline no one & 65.0 & 52.4 & 56.4 & 55.2 \\
\hline Number of observations & 200 & 124 & 204 & 29 \\
\hline \multicolumn{5}{|l|}{ What was the final outcome? } \\
\hline wrote off debt completely & 10.8 & 19.4 & 16.4 & 35.7 \\
\hline negotiated partial settlement & 47.7 & 47.3 & 52.7 & 42.9 \\
\hline recovered loss in full & 41.5 & 33.3 & 30.9 & 21.4 \\
\hline Number of observations & 195 & 129 & 207 & 28 \\
\hline $\begin{array}{l}\text { Is firm still a customer? (\% } \\
\text { responding, "yes") }\end{array}$ & 62.3 & 62.2 & 66.4 & 53.3 \\
\hline Number of observations & 204 & 135 & 211 & 30 \\
\hline
\end{tabular}




\section{Table 3C. Most Recent Payment Dispute with Customer}

Trade association member

Not trade

Which organization(s) assisted?

court

private (formal or informal) agency

court and private agency

no one

Number of observations

\section{What was the final outcome?}

wrote off debt completely

negotiated partial settlement

recovered loss in full

Number of observations

Is the firm still a customer? (\% responding, "yes")

Number of observations
38.7

2.8

2.4

56.1

212

11.8

47.2

41.0

212

43.6

220
34.8

5.2

0.3

59.7

345

18.7

50.4

30.8

347

32.6

359 
Table 4A. Did Court Assist in Resolving Most Recent Payment Dispute with Customer

\section{All Disputes}

Supplier characteristics

Trade association membership

Log age

Log employees

$>25 \%$ state owned

$>25 \%$ foreign owned

Log customers

Log customers new in past year

Log firms located in same city

Profitability in previous year

\section{Relationship / customer}

characteristics

Located close to, but not in,

same city as supplier

Located elsewhere in country

Located abroad

Log months a customer

State owned

Distance and institutional

\section{interaction}

Located elsewhere $\mathrm{x}$ trade

association membership

Country of supplier control

Sector of supplier control

Additional supplier controls

Year of dispute control

Prob $>$ chi2

Number of observations

Pseudo R-square

\section{All Disputes}

$$
\begin{gathered}
0.063 \\
(1.24) \\
0.054 \\
(1.22) \\
0.053^{* *}
\end{gathered}
$$

(1.99)

0.131

(1.23)

$-0.018$

(0.15)

0.005

(0.14)

$0.060^{*}$

(1.69)

0.004

(0.19)

$-0.025$

(0.94)

$0.130 * *$

(1.99)

0.076

(1.18)

0.057

(0.41)

$-0.010$

(0.60)

$-0.030$

(0.49)

$0.130^{* *}$

(2.13)

0.055

(1.25)

$0.054^{* *}$

(2.02)

0.122

(1.14)

$-0.020$

(0.16)

0.006

(0.16)

$0.063^{*}$

(1.78)

0.004

(0.21)

$-0.027$

(0.99)

$0.131^{* *}$

(1.99)

$0.156^{* *}$

(2.06)

0.071

(0.51)

$-0.012$

(0.74)

$-0.034$

(0.56)
$-0.166^{*}$

(1.84)

Yes

Yes

Yes

Yes

0.0000

504

.1234
Disputants located either close to or in same city

$0.149 * *$

(2.22)

0.085

(1.46)

0.053

(1.42)

0.062

(0.51)

$-0.210$

(1.44)

0.011

$(0.21)$

0.060

(1.14)

$-0.014$

$(0.50)$

$-0.006$

(0.16)

$0.155^{* *}$

(2.23)

$-0.047 * *$

(2.14)

$-0.005$

(0.06)

Notes: Marginal effects from the probit regression are reported; * indicates 0.10 level, ** 0.05 level, *** 0.01 level.; absolute value of $\mathrm{t}$-stats reported in parentheses. 
Table 4B. Degree of Payment Recovery (Zero, Partial or Full)

Supplier characteristics

Trade association membership

Log age

Log employees

$>25 \%$ state owned

$>25 \%$ foreign owned

Log customers

Log customers new in past year

Log firms located in same city

Profitability in previous year

Relationship / customer characteristics

Located in same city as supplier

Located close to but not in same city

Located elsewhere

Log months a customer

State owned

\section{Evolution of dispute}

Did court help resolve

Did court help resolve $\mathrm{x}$ trade association membership

Country of supplier control

Sector of supplier control

Additional supplier controls

Year of dispute control

Prob > chi2

Number of observations

Pseudo R-square

\section{All Disputes}

$\begin{array}{ll}\text { Debt fully } & \text { Debt fully } \\ \text { written off } & \text { recovered }\end{array}$

$\begin{array}{cc}-.056 * * & .097 * * \\ (2.30) & (2.24) \\ -.003 & .004 \\ (0.11) & (0.11) \\ .009 & -.014 \\ (0.61) & (0.60) \\ -.087 * * * & .202^{*} \\ (2.59) & (1.84) \\ .022 & -.034 \\ (0.31) & (0.33) \\ -.048 * * * & .080 * * \\ (2.60) & 2.54 \\ .049 * * * & -.082 * * * \\ (2.72) & (2.69) \\ .005 & -.009 \\ (0.52) & (0.52) \\ .041 * * * & -.069 * * *\end{array}$

(3.23)

$-.190^{* * *}$

(3.47)

$-.144 * * *$

(3.37)

$-.145^{* * *}$

(2.63)

$-.008$

(1.01)

$-.021$

$(0.71)$

$.117^{* * *}$

(3.70)

$.369 * * *$

$(3.24)$
$320 * * *$

(2.66)

$.276^{* *}$

(2.41)

.014

(1.02)

.036

(0.68)

$-174 * * *$

Disputants located

in same country

$\begin{array}{ll}\begin{array}{l}\text { Debt fully } \\ \text { written off }\end{array} & \begin{array}{l}\text { Debt fully } \\ \text { recovered }\end{array}\end{array}$

$\begin{array}{cc}-.050 * & .090 * \\ (1.71) & (1.67) \\ -.001 & .001 \\ (0.03) & (0.03) \\ .011 & -.019 \\ (0.79) & (0.79) \\ -.074 * * & .176 \\ (2.20) & (1.64) \\ .030 & -.049 \\ (0.41) & (0.45) \\ -.044 * * & .079 * * \\ (2.47) & 2.41 \\ .045 * * & -.080 * * \\ (2.53) & (2.51) \\ .008 & -.013 \\ (0.75) & (0.75) \\ .039 * * * & -.069 * * * \\ (3.10) & (3.05)\end{array}$

(3.10)

$-.044$

(1.48)

$-.020$

(1.43)

(0.68)

$-.006$

.011

(0.77)

(0.77)

$-.017$

.031

(0.60)

(0.58)

$.139 * * *$

$-.215^{* * *}$

(3.38)

(3.95)

$-.040$

.078

(0.99)

(0.89)

$\begin{array}{cc}\text { Yes } & \text { Yes } \\ \text { Yes } & \text { Yes } \\ \text { Yes } & \text { Yes } \\ \text { Yes } & \text { Yes } \\ & \\ 0.0000 & 0.0000 \\ 490 & 465 \\ .0814 & .0772\end{array}$

Notes: Marginal effects from the ordered probit regression are reported but only for the "extreme" outcomes (i.e., not for partial debt recovery); because of a small number of observations, three of ten sectors were combined allowing STATA to compute the marginal effects for the ordered probit; * indicates 0.10 level, ** 0.05 level, *** 0.01 level.; absolute value of t-stats reported in parentheses. 
Table 4C. Relationship Maintained after the Dispute

\begin{tabular}{|c|c|c|}
\hline & All Disputes & $\begin{array}{l}\text { Disputants located } \\
\text { in same country }\end{array}$ \\
\hline \multicolumn{3}{|l|}{ Supplier characteristics } \\
\hline \multirow[t]{2}{*}{ Trade association membership } & $0.103^{*}$ & $0.104^{*}$ \\
\hline & $(1.92)$ & $(1.96)$ \\
\hline \multirow[t]{2}{*}{ Log age } & -0.027 & -0.037 \\
\hline & $(0.55)$ & $(0.73)$ \\
\hline \multirow[t]{2}{*}{ Log employees } & 0.033 & 0.026 \\
\hline & $(1.13)$ & $(0.92)$ \\
\hline \multirow[t]{2}{*}{$>25 \%$ state owned } & 0.052 & 0.075 \\
\hline & $(0.42)$ & $(0.60)$ \\
\hline \multirow[t]{2}{*}{$>25 \%$ foreign owned } & 0.113 & 0.089 \\
\hline & $(0.91)$ & $(0.65)$ \\
\hline \multirow[t]{2}{*}{ Log customers } & 0.022 & 0.032 \\
\hline & $(0.58)$ & $(0.83)$ \\
\hline \multirow[t]{2}{*}{ Log customers new in past year } & -0.029 & -0.037 \\
\hline & $(0.80)$ & $(0.98)$ \\
\hline \multirow[t]{2}{*}{ Log firms located in same city } & $-0.042 *$ & $-0.046^{* *}$ \\
\hline & $(1.83)$ & $(2.05)$ \\
\hline \multirow[t]{2}{*}{ Profitability in previous year } & 0.042 & $0.050^{*}$ \\
\hline & $(1.45)$ & $(1.71)$ \\
\hline \multicolumn{3}{|c|}{ Relationship / customer characteristics } \\
\hline \multirow[t]{2}{*}{ Located elsewhere } & $-0.150 * * *$ & -0.061 \\
\hline & $(2.79)$ & $(0.93)$ \\
\hline \multirow[t]{2}{*}{ Located abroad } & 0.203 & \\
\hline & $(1.54)$ & \\
\hline \multirow[t]{2}{*}{ Log months a customer } & $-0.029 *$ & -0.024 \\
\hline & $(1.69)$ & $(1.37)$ \\
\hline \multirow[t]{2}{*}{ State owned } & $0.165^{* *}$ & $0.148^{* *}$ \\
\hline & $(2.54)$ & $(2.32)$ \\
\hline \multicolumn{3}{|c|}{ Distance and institutional interaction } \\
\hline \multicolumn{2}{|c|}{ Located elsewhere $\mathrm{x}$ did court } & $-0.267 * * *$ \\
\hline help resolve & & $(2.80)$ \\
\hline \multicolumn{3}{|l|}{ Evolution of dispute } \\
\hline \multirow[t]{2}{*}{ Did court help resolve } & $-0.327 * * *$ & $-0.232 * * *$ \\
\hline & $(6.32)$ & $(3.44)$ \\
\hline \multirow{2}{*}{$\begin{array}{l}\text { Degree to which payment } \\
\text { recovered }\end{array}$} & $0.131^{* * *}$ & $0.132^{* * *}$ \\
\hline & $(3.60)$ & $(3.58)$ \\
\hline \multirow{4}{*}{$\begin{array}{l}\text { Country of supplier control } \\
\text { Sector of supplier control } \\
\text { Additional supplier controls } \\
\text { Year of dispute control }\end{array}$} & Yes & Yes \\
\hline & Yes & Yes \\
\hline & Yes & Yes \\
\hline & Yes & Yes \\
\hline \multirow{3}{*}{$\begin{array}{l}\text { Prob > chi } 2 \\
\text { Number of observations } \\
\text { Pseudo R-square }\end{array}$} & 0.0000 & 0.0000 \\
\hline & 489 & 464 \\
\hline & .2612 & .2692 \\
\hline \multicolumn{3}{|c|}{$\begin{array}{l}\text { Notes: Marginal effects from the probit regression are reported; (i) * indicates } 0.10 \text { level, ** } 0.05 \text { level, *** } 0.01 \text { level.; } \\
\text { absolute value of t-stats reported in parentheses. }\end{array}$} \\
\hline
\end{tabular}




\section{Sources Cited}

Anderson, James, Marcouiller, Douglas, 2002. Insecurity and the Pattern of Trade: An Empirical Investigation. Review of Economics and Statistics 84, 345-352.

Anderson, James, van Wincoop, Eric, 2004. Trade Costs. Journal of Economic Literature 42, 691-751.

Bigsten, Arne, Collier, Paul, Dercon, Stefan, Fafchamps, Marcel, Gauthier, Bernard, Gunning, Jan W., Oduro, Abena, Oostendorp, Remco, Patillo, Cathy, Soderbom, Mans, Teal, Francis, Zeufack, Albert, 2000. Contract Flexibility and Dispute Resolution in African Manufacturing. Journal of Development Studies 36, 1-37.

Broadman, Harry, Anderson, James, Claessens, Constantijn, Ryterman, Randi, Slavova, Stefka, Vagleasindi, Maria, Vencellette, Gallina, 2004. Building Market Institutions in South Eastern Europe: Comparative Prospects for Investment and Private Sector Development. International Bank for Reconstruction and Development, Washington, DC.

Cheit, Ross, Gersen, Jacob, 2000. When Businesses Sue Each Other: An Empirical Study of State Court Litigation. Law and Social Inquiry 25, 798-816.

Cooter, Robert, Rubinfeld, Daniel, 1989. Economic Analysis of Legal Disputes and their Resolution. Journal of Economic Literature 27, 1067-1097.

Dietrich, Mark, 2000. Legal and Judicial Reform in Central Europe and the Former Soviet Union: Voices from Five Countries. International Bank for Reconstruction and Development, Washington, DC.

Djankov, Simeon, La Porta, Rafael, Lopez-de-Silanes, Florencio, Shleifer, Andrei, 2003. Courts. Quarterly Jounal of Economics 118, 453-517.

Doner, Richard and Schneider, Ben R., 2000. Business Associations and Economic Development: Why Some Associations Contribute More Than Others. Business and Politics 2, 261-288.

Farmer, Amy, Pecorino, Paul, 1998. Frivolous Lawsuits and Fee Shifting in a Repeated Play Game. International Review of Law and Economics 18, 147-157. 
Felstiner, William L.F., Abel, Richard, Sarat, Austin, 1980-81. The Emergence and Transformation of Disputes: Naming, Blaming, Claiming. Law and Society Review 15, 631654.

Frye, Timothy, 2002. Capture or Exchange? Business Lobbying in Russia. Europe-Asia Studies 54, 1017-1036.

Frye, Timothy and Zhuravskaya, Ekaterina, 2000. Rackets, Regulation and the Rule of Law. Journal of Law, Economics and Organization 16, 478-502.

Greif, Avner, 1993. Contract Enforceability and Economic Institutions in Early Trade: The Maghribi Traders Coalition. American Economic Review 83, 525-548.

Greif, Avner, Kandel, Eugene, 1995. Contract Enforcement Institutions. In Lazear, Ed, (Ed.), Economic Transition in Eastern Europe and Russia. Hoover Institution Press, Stanford, CA.

Hellman, Joel S., Jones, Geraint, Kaufmann, Daniel, 2003. Seize the State, Seize the Day: State Capture and Influence in Transition Economies. Journal of Comparative Economics 31, 751773.

Hendley, Kathryn, 2001. Beyond the Tip of the Iceberg: Business Disputes in Russia. In: Murell, Peter, (Ed.), Assessing the Value of Law in Transition Economies. University of Michigan Press, Ann Arbor, MI.

Hendley, Kathryn, 2004. Business Litigation in the Transition: A Portrait of Debt Collection in Russia. Law and Society Review 38, 305-347.

Hendley, Kathryn, Murrell, Peter, 2003. Which Mechanisms Support the Fulfillment of Sales Agreements? Asking Decision-Makers in Firms. Economics Letters 78, 49-54.

Hendley, Kathryn, Ickes, Barry, Murrell, Peter, Ryterman, Randi, 1997. Observations on the Use of Law by Russian Enterprises. Post-Soviet Affairs 13, 19-41.

Johnson, Simon, Kaufmann, Daniel, McMillan, John, Woodruff, Christopher, 2000. Why do Firms Hide? Bribes and Unofficial Activity After Communism. Journal of Public Economics $76,495-520$.

Johnson, Simon, McMillan, John, Woodruff, Christopher, 2002a. Courts and Relational Contracts. Journal of Law, Economics and Organization 18, 221-277. 
, 2000. Entrepreneurs and the Ordering of Institutional Reform. Economics of Transition 8, 1-36. , 2002b. Property Rights and Finance. American Economic Review 92, 1335-56.

Kagan, Robert, 1984. The Routinization of Debt Collection: An Essay on Social Change and Conflict in the Courts. Law and Society Review 18, 323-371.

Kenworthy, Lane, Macaulay, Stewart, Rogers, Joel, 1996. 'The More Things Change'...: Business Litigation and Governance in the American Automobile Industry. Law and Social Inquiry 21, 631-678.

Leitzel, Jim, Alexeev, Michael, Gaddy, Clifford, 1995. Mafiosi and Matrioshki: Organized Crime and Russian Reform. The Brookings Review 13 (Winter), 26-29.

McMillan, John, Woodruff, Christopher, 1999a. Dispute Prevention without Courts in Vietnam. Journal of Law, Economics and Organization 15, 637-658.

, 1999b. Interfirm Relationships and Informal Credit in Vietnam. Quarterly Journal of Economics 98, 1285-1320.

Macaulay, Stewart, 1963. Non-Contractual Relations in Business: A Preliminary Study. American Sociological Review 28, 55-67.

, 1977. Elegant Models, Empirical Pictures and the Complexities of Contract. Law and Society Review 11, 507-528.

Milgrom, Paul, North, Douglass, Weingast, Barry, 1990. The Role of Institutions in the Revival of Trade: The Medieval Law Merchant, Private Judges, and the Champagne Fairs. Economics and Politics 2, 1-23.

North, Douglass C., 1990. Institutions, Institutional Change and Economic Performance. Cambridge University Press, New York, NY.

Olson, Mancur, 1982. The Rise and Decline of Nations, Yale University Press, New Haven, CT.

Priest, George L., Klein, Benjamin, 1984. The Selection of Disputes for Litigation. Journal of Legal Studies 13, 1-55. 
Pyle, William, 2005. Contractual Disputes and the Channels for Inter-firm Communication. Journal of Law, Economics and Organization, 21.

Rajan, Raghuram Zingales, Luigi, 1995. What Do We Know about Capital Structure? Some Evidence from International Data. Journal of Finance 50, 1421-1460.

Ramasastry, Anita, 2002. What Local Lawyers Think: A Retrospective on the EBRD's Legal Indicator Surveys. Law in Transition (Autumn), 14-30.

Rodrik, Dani, 2000. How Far Will International Economic Integration Go? Journal of Economic Perspectives 14, 177-186.

Schaffer, Mark, 1998. Do Firms in Transition Economies Have Soft Budget Constraints? A Reconsideration of Concepts and Evidence. Journal of Comparative Economics 26, 80-103.

Smith, Adam, 1976. An Inquiry into the Nature and Causes of the Wealth of Nations. Chicago University Press, Chicago, IL.

Varese, Federico, 2001. The Russian Mafia: Private Protection in a New Market Economy. Oxford University Press, New York, NY.

Williamson, Oliver, 1996. The Mechanisms of Governance, Oxford University Press, New York, NY.

Woodruff, Christopher, 1998. Contract Enforcement and Trade Liberalization in Mexico's Footwear Industry. World Development 26, 979-991.

World Development Report 2002: Building Institutions for Markets. Oxford University Press. 
${ }^{1}$ The author would like to thank Timothy Frye, Peter Matthews and seminar participants at Middlebury College for their helpful comments.

${ }^{2}$ Better institutions encourage firms to engage in transactions that they might have otherwise avoided and though they may lower the probability that any given transaction will lead to a dispute, they may increase the number of transactions and, thereby, the number of disputes.

${ }^{3}$ In addition to the cited article, which provides the most comprehensive description of the survey project, Johnson, McMillan and Woodruff, the lead investigators published a number of noteworthy articles using these data (Johnson, Kaufmann, McMillan and Woodruff, 2000; Johnson et al., 2002a; and Johnson et al., 2002b) before placing them in the public domain.

${ }^{4}$ Hendley (2004), moreover, contends that their relative simplicity makes them more transparent and thus less prone to corrupt influences if resolved in government courts.

${ }^{5}$ These authors demonstrate that firms' expression of confidence in the courts and their use of common modes of relational contracting are associated with a greater willingness to initiate dealings with new, price-competitive suppliers and to extend trade credit to existing customers.

${ }^{6}$ In 1997, the European Bank for Reconstruction and Development assessed the cross-country variation in legal system by directly querying a number of legal experts familiar with the region. On a four-point scale, a plurality of former socialist countries scored a 2 in 1997, indicating that "[c]ommercial legal rules are generally unclear and sometimes contradictory." Two countries that feature in our analysis, Romania and Slovakia, rated a 3, meaning that though "commercial legal rules are reasonably clear, administration or judicial support of the law appears to be often inadequate or inconsistent." The legal experts gave Poland the highest rank; its commercial laws were judged to be "reasonably clear and [its] administrative and judicial support of the law is reasonably consistent."

${ }^{7}$ Judges in Poland have complained about the difficulties of keeping up with changes to the law. And many judges are appointed right out of law school and have little practical understanding of business affairs. One lawyer commented to a Western expert conducting a study for the World Bank (Dietrich, 2000) that "Sometimes things are too complicated for the judges... They are very 
young, and receive a very good theoretical education, but they do not understand how business works.'

${ }^{8}$ One Polish official noted the country's problem with collecting debts, explaining it as a legacy of the communist system in which "debtors received more protection than creditors." Bailiffs were prone to being influenced by the debtors (Dietrich, 2000).

${ }^{9}$ This project collected data from questionnaires answered by attorneys at leading law firms in 109 countries. Questions addressed the evolution of a check collection procedure before the local courts in the country's largest city.

${ }^{10}$ On the basis of data collected through Business Environment and Economic Performance Survey in 2002, Broadman et al. (2004) report that only 10\% of Romanian firms that are association members report that an association to which they belong "provides major or critical value in resolving disputes." The authors, however, do note that there are some firms in the region that have used chambers of commerce because local courts are slow. These inquiries do not appear to touch on associations' role in supporting relational contracting.

${ }^{11}$ Surveys were also administered in Russia and Ukraine but the coverage of payment dispute specifics was much more limited; indeed, several of the relevant questions appear not even to have been asked. In Poland, the respondents were firms in Katowice; in Romania, Brasov; and in Slovakia, roughly half of the firms were from Kosice and Bratislava with the rest coming from one of seven other cities. The firms represented the following branches within manufacturing: metal, wood, food and chemical products, clothes, construction materials, paper and packaging, handicrafts and electrical machinery.

${ }^{12}$ The pattern of cross-country variation here is a bit surprising. Notably Poland, which by some accounts had the region's most sophisticated legal system (Ramasastry, 2002), has a relatively high percentage of firms that express no confidence in formal contract enforcement institutions; Romania, however, which is widely considered to have been a relative laggard in terms of institutional development, has courts that inspire the most confidence. Also somewhat surprisingly, there appears to be an inverse relationship at the country level between the belief that no third parties can enforce agreements and the choice not to use third parties to enforce contracts. Notably, relative to those in Poland and Slovakia, a lesser percentage of Romanian 
firms actually report calling on other organizations to help them resolve disputes even though a greater percentage report having confidence in the ability of third parties, including courts, to enforce contracts.

${ }^{13}$ The response "local government" is merged with "court" given the small numbers $-0.8 \%$ of all firms - associated with the former.

${ }^{14}$ Of course, it is possible that a seller does not inform the buyer of his grievance in which case the dispute never goes beyond the first stage. Felstiner et al. (1980-81) refer to the occurrence of the violation as the first - or the "naming" - stage. A subsequent appeal to the buyer is referred to as the "blaming" stage. We think it unlikely that the respondents to the survey - answering questions about "your most recent payment dispute" with a customer - would have thought of incidents that progressed no further than this first stage. Felstiner et al. include any appeals to private mediators as a part of this blaming stage.

${ }^{15}$ As part of the Lex Mundi project (Djankov et al., 2003), lawyers in a number of countries were asked about a hypothetical case in which a creditor tries to use the court system to collect an overdue payment - equal to .5\% of GNI per capita - on a fulfilled contract. In Romania, for instance, this would amount to a debt of $\$ 830$. Expected attorney fees in such a case would be roughly $\$ 120$ and expected court fees would be roughly $\$ 8$ (Broadman et al., 2004). Dietrich (2000) points out that that filing fees have excluded some parties from accessing courts in transition economies. And in Poland, he notes that judges have been reluctant to waive these fees because they constitute an important source of funding for the courts. In the exceptions when they are waived, it is through ex parte negotiations between litigants and judges, thus raising the potential for corruption.

${ }^{16}$ Judges in Poland have complained about the difficulties of keeping up with changes to the law. And many judges are appointed right out of law school and have little practical understanding of business affairs. One lawyer commented to a Western expert conducting a study for the World Bank (Dietrich, 2000) that "[s]ometimes things are too complicated for the judges... They are very young, and receive a very good theoretical education, but they do not understand how business works." 
${ }^{17}$ One Polish official noted the country's problem with collecting debts, explaining it as a legacy of the communist system in which "debtors received more protection than creditors."

${ }^{18}$ The author's conversations with personnel at the Center for International Private Enterprise (an independent, non-profit affiliate of the U.S. Chamber of Commerce that offers assistance to nascent business organizations through the post-socialist world) confirmed that many of the associations in Poland, Slovakia and Romania provide constituents with a regular flow of information on the evolving legal system. Moreover, in a survey of 200 business associations conducted by the author in Russia in the summer of 2004, $85 \%$ reported offering their clients information related to changes in laws and regulations. When asked to evaluate the importance of this service to their members, the mean response of the association managers on a Likert scale from 1 ("not at all important") to 5 ("extremely important") was 4.41.

${ }^{19}$ The authors find that $81 \%$ of small firms in the BEEPS survey (fewer than 50 full-time employees), $57 \%$ of medium-size firms $(50-249)$ and $38 \%$ of large firms report that report that none of their payment disputes were resolved in court.

${ }^{20}$ Broadman et al. (2004) present evidence that small firms are particularly unlikely to have inhouse counsel.

${ }^{21}$ Broadman et al. (2004) find that state firms, across the region, are more informed about laws and regulations and that they find courts' interpretations of them more consistent and predictable. They also report that state-owned firms have a higher proportion of payment disputes resolved in court. We should note, however, that these are bilateral relationships.

${ }^{22}$ Hendley (2004) finds that $14 \%$ of firms filing suit in Russian non-payment cases filed the suit in order to "send a message to other customers that not paying is unacceptable?" She argued the number was not higher because case decisions are not published and, therefore, are unlikely to become known to third parties.

${ }^{23}$ The dependent variable takes on the value of 0 if the dispute was resolved either without any outside assistance or with the help of a private agency - with the latter constituting less than $5 \%$ of all reported payment disputes. 
${ }^{24} \mathrm{We}$ exclude from the analysis the five firms that used both the court system and a private agency.

${ }^{25}$ In this and all subsequent regressions, controls are included for the percentage of the firm's total sales made to customers of different ownership types (e.g., state enterprise, privatized firms, greenfields, etc.) and client locations vis a vis the firm (e.g., in the same city, elsewhere in the country, abroad).

${ }^{26}$ It might be presumed that willingness to join a business organization is a proxy for willingness to operate in the formal sector of the economy. The positive association between business association membership and using the courts might thus be explained by this third variable. However, when running the models presented in Table 4A with a variable that has been used by others to capture informality - hidden sales as a percentage of actual sales for "firms in your industry" (Johnson, Kaufmann, McMillan and Woodruff, 2000) - the magnitude and statistical significance of our variables of interest do not change in the least.

27 There are also some noteworthy macro-level effects. Firms in Romania are much less likely to rely upon the court system in resolving a dispute than are firms in Poland; this is consistent with the evaluation of legal experts that the Polish court system is more effective than the Romanian. Moreover, we should note that disputes that occurred earlier are more likely to have ended up in court. Since the language of the survey makes clear that the questions refer to disputes that have ended or been resolved, this finding suggests that contrary to conventional wisdom, recourse to courts for a standard business dispute is becoming less common with time. This perhaps can be understood as a result of a greater understanding of the costs of litigation or more experience with non-litigious mechanisms for dispute resolution.

${ }^{28}$ The role of association membership is not sensitive to the geographic distance between the firms in the manner observed in the litigation regressions - i.e., there is no statistically significant effect of the interaction between association membership and the customer being located "elsewhere in the country."

${ }^{29}$ In another variant of the association-as-informational-node story, there is a good deal of evidence that business organizations provide members with access to information about the reliability of business partners (Macaulay, 1963; Doner and Schneider, 2000; Pyle, 2005; 
Woodruff, 1998). It is thus possible that association members are more likely to be involved in disputes with customers that experience only temporary as opposed to permanent payment difficulties. In other words, business association membership may be correlated with the dispute's severity, a variable that we do not observe.

${ }^{30}$ The inclusion of this control makes more sense within the context of a model restricted to intra-country disputes. We have no reason to believe that business associations from one country can exercise influence over public institutions in another.

${ }^{31}$ Firms that have established relationships with fewer new customers in the past year are more likely to have satisfactorily resolved their dispute. It is possible that, ceteris paribus, a firm with less turnover in its client base is able to devote more resources to screening per each new customer. This may mean that they are more likely than those that screen less to be dealing with more reliable customers whose payment difficulties are relatively more likely to be temporary than permanent. That is, again, a variable may be proxying for the dispute's severity.

${ }^{32}$ The termination of the relationship may have been due to circumstances unrelated to the dispute, but the data, however, do not allow us to distinguish these cases. We only know whether or not the firm in question remained a customer of the respondent at the time of the survey.

${ }^{33} \mathrm{We}$ also see some evidence that firms that have a long and enduring relationship are more likely to have that relationship derailed in the aftermath of a payment dispute. Although the statistical significance of this finding does not hold up in the model that includes just intracountry disputes (see column 2), this is a surprising result, since it has been suggested that longer relationships allow partners to build up a better capacity to cooperate and work through difficulties (Macaulay, 1963; Macaulay, 1977). Moreover, one might suspect that in a long relationship, the impact of one piece of information - a single unpaid bill - would be less damaging to the supplier's evaluation of the customer than in a relationship in which the parties share less of a history together. 


\section{DAVIDSON INSTITUTE WORKING PAPER SERIES - Most Recent Papers}

The entire Working Paper Series may be downloaded free of charge at: www.wdi.bus.umich.edu

CURRENT AS OF 3/29/05

\begin{tabular}{|c|c|c|}
\hline Publication & Authors & Date \\
\hline $\begin{array}{l}\text { No. 761: Resolution, Recovery and Survival: The Evolution of Payment } \\
\text { Disputes in Post-Socialist Europe }\end{array}$ & William Pyle & Mar. 2005 \\
\hline $\begin{array}{l}\text { No. 760: Official Foreign Exchange Interventions in the Czech } \\
\text { Republic: Did They Matter? }\end{array}$ & Balázs Égert and Luboš Komárek & Mar. 2005 \\
\hline $\begin{array}{l}\text { No. 759: Assessing Market Expectations on Exchange Rates and } \\
\text { Inflation: A Pilot Forecasting System for Bulgaria }\end{array}$ & $\begin{array}{l}\text { Michael Berlemann, Kalina } \\
\text { Dimitrova, \& Nikolay Nenovsky }\end{array}$ & Mar. 2005 \\
\hline No. 758: Attitudes and Performance: An Analysis of Russian Workers & $\begin{array}{l}\text { Susan J. Linz and Anastasia } \\
\text { Semykina }\end{array}$ & Mar. 2005 \\
\hline $\begin{array}{l}\text { No. 757: Barter, Credit, and Welfare: A theoretical inquiry into the } \\
\text { barter phenomenon in Russia }\end{array}$ & José Noguera and Susan J. Linz & Mar. 2005 \\
\hline $\begin{array}{l}\text { No. 756: Sorting, Selection, and Transformation of the Return to } \\
\text { College Education In China }\end{array}$ & $\begin{array}{l}\text { Belton M. Fleisher, Haizheng Li, } \\
\text { Shi Li, and Xiaojun Wang }\end{array}$ & Mar. 2005 \\
\hline $\begin{array}{l}\text { No. 755: Foreign Exchange Interventions in Emerging Europe: } \\
\text { Should We Give a Damn? The Case of Croatia and Turkey }\end{array}$ & Balázs Égert & Mar. 2005 \\
\hline $\begin{array}{l}\text { No. 754: Targeting Relative Inflation Forecast as Monetary Policy } \\
\text { Framework for Adopting Euro }\end{array}$ & Lucjan T. Orlowski & Feb. 2005 \\
\hline $\begin{array}{l}\text { No. 753: Internet Entrepreneurship: Networks and Performance of } \\
\text { Internet Ventures In China }\end{array}$ & Bat Batjargal & Feb. 2005 \\
\hline $\begin{array}{l}\text { No. 752: Network Triads: Transitivity, Referral and Venture Capital } \\
\text { Decisions in China and Russia }\end{array}$ & jargal & Feb. 2005 \\
\hline $\begin{array}{l}\text { No. 751: Software Entrepreneurship: Knowledge Networks and } \\
\text { Performance Of Software Ventures In China and Russia }\end{array}$ & Bat Batjargal & Feb. 2005 \\
\hline $\begin{array}{l}\text { No. 750: Retained State Shareholding in Chinese PLCs: Does } \\
\text { Government Ownership Reduce Corporate Value? }\end{array}$ & Lihui Tian and Sal & Feb. 2005 \\
\hline No. 749: Financial Development and Technology & Solomon Tad & Feb. 2005 \\
\hline No. 748: Banking Fragility and Disclosure: International Evidence & Solomon Tadesse & Feb. 2005 \\
\hline $\begin{array}{l}\text { No. 747: Consolidation, Scale Economies and Technological Change in } \\
\text { Japanese Banking }\end{array}$ & Solomon Tadesse & Feb. 2005 \\
\hline $\begin{array}{l}\text { No. 746: Trade Creation and Diversion Effects of Europe’s Regional } \\
\text { Liberalization Agreements }\end{array}$ & Yener Kandogan & Feb. 2005 \\
\hline No. 745: Quality of Institutions, Credit Markets and Bankruptcy & Christa Hainz & Feb. 2005 \\
\hline $\begin{array}{l}\text { No. 744: How Transition Paths Differ: Enterprise Performance in Russia } \\
\text { and China }\end{array}$ & Sumon Bhaumik and Saul Estrin & Jan. 2005 \\
\hline $\begin{array}{l}\text { No. 743: Inflation Targeting, Between Rhetoric and Reality. The Case } \\
\text { of Transition Economies }\end{array}$ & Daniel Daianu and Laurian Lungu & Jan. 2005 \\
\hline $\begin{array}{l}\text { No. 742: How Does Law Affect Finance? An Empirical Examination of } \\
\text { Tunneling in an Emerging Market }\end{array}$ & $\begin{array}{l}\text { Vladimir Atanasov, Conrad S. } \\
\text { Ciccotello, \& Stanley B. Gyoshev }\end{array}$ & Jan. 2005 \\
\hline $\begin{array}{l}\text { No. 741: Do Insider Trading Laws Matter? Some Preliminary } \\
\text { Comparative Evidence }\end{array}$ & Laura Nyantung Beny & Jan. 2005 \\
\hline $\begin{array}{l}\text { No. 740: Autopsy on an Empire: Understanding Mortality in Russia and } \\
\text { the Former Soviet Union }\end{array}$ & $\begin{array}{l}\text { Elizabeth Brainerd and David M. } \\
\text { Cutler }\end{array}$ & Jan. 2005 \\
\hline $\begin{array}{l}\text { No. 739: Not Separate, Not Equal: Poverty and Inequality in Post- } \\
\text { Apartheid South Africa }\end{array}$ & $\begin{array}{l}\text { Johannes G. Hoogeveen and Berk } \\
\text { Özler }\end{array}$ & Jan. 2005 \\
\hline $\begin{array}{l}\text { No. 738: The Marketing Structure in Agribusiness during the Transition } \\
\text { in Bulgaria }\end{array}$ & $\begin{array}{l}\text { Steve Murray, Yordan Staykov, } \\
\text { and Valentin Katzerov }\end{array}$ & Jan. 2005 \\
\hline No. 737: Passive Creditors & $\begin{array}{l}\text { Koen Schoors and Konstantin } \\
\text { Sonin }\end{array}$ & Jan. 2005 \\
\hline $\begin{array}{l}\text { No. 736: From a currency board to the euro: Public attitudes toward } \\
\text { unilateral euroization in Bulgaria }\end{array}$ & Neven T. Valev & Jan. 2005 \\
\hline No. 735: Dictators and Their Viziers: Agency Problems in Dictatorships & $\begin{array}{l}\text { Georgy Egorov and Konstantin } \\
\text { Sonin }\end{array}$ & Jan. 2005 \\
\hline
\end{tabular}

